$3-28-2018$

\title{
German and American Transnational Spaces in Women's and Gender History
}

Shelley Rose

Cleveland State University, shelley.rose@csuohio.edu

Follow this and additional works at: https://engagedscholarship.csuohio.edu/clhist_facpub

Part of the European History Commons, History of Gender Commons, Social History Commons, United States History Commons, and the Women's History Commons

How does access to this work benefit you? Let us know!

\section{Publisher's Statement}

Copyright (C) 2018 The Johns Hopkins University Press. This article first appeared in Journal of Women's History, Volume 30, Issue 1, March 2018, 163-9. http://muse.jhu.edu/article/689111

\section{Original Citation}

German and American Transnational Spaces in Women's and Gender History. Journal of Women's History. Vol. 30, Iss. 1, March 28, 2018, pp. 163-169. http://rave.ohiolink.edu/ejournals/article/352135771

\section{Repository Citation}

Rose, Shelley, "German and American Transnational Spaces in Women's and Gender History" (2018). History Faculty Publications. 108.

https://engagedscholarship.csuohio.edu/clhist_facpub/108

This Book Review is brought to you for free and open access by the History Department at EngagedScholarship@CSU. It has been accepted for inclusion in History Faculty Publications by an authorized administrator of EngagedScholarship@CSU. For more information, please contact library.es@csuohio.edu. 


\title{
German and American Transnational Spaces in Women's and Gender History
}

\author{
Shelley E. Rose
}

$\mathrm{T}$

ransatlantic relationships between Germans and Americans provide scholars with a rich selection of materials for comparative, transnational, and entangled histories from the nineteenth century to the present. Many of these studies are characterized by the physical mobility of Germans and Americans. These groups included German labor and political migrants to the United States and American soldiers who went to Germany during the World Wars and their aftermath. In recent years, scholars have turned their attention to a third area: the construction of transatlantic spaces that fostered cultural and intellectual exchange. One factor that distinguishes three recent transatlantic books-Lynn Tatlock's German Writing, American Reading, Michaela Bank's Women of Two Countries, and Karen Hagemann and Sonya Michel's Gender and the Long Postwar-is a distinct focus on the lived and transnational experiences of historical actors within the United States and Germany. Methodologically and chronologically diverse, these three books explore several common themes, bringing individual agency to the forefront of German-American encounters. Each study reveals transatlantic dialogues on gender roles and the family that are often grounded, interestingly, in a single national context. In the case of Gender and the Long Postwar, the editors extend this framework to include analytical connections between "entangled" German and American historiographies (4).

Tatlock, a German studies scholar, argues in her book, German Writing, American Reading, for increased scholarly attention to popular literature in 
the United States, citing the historian William St. Clair's call for scholarship on books that were "actually read," instead of the accepted cannon (5). Her innovative approach examines the lived reading experiences of American women and challenges traditional historiography on the book trade by focusing on American translators of German-authored fiction. These translators served as cultural agents, according to Tatlock, creating transatlantic space by marketing their books in the United States as hybrid cultural "products" (12).

German Writing, American Reading is organized into three main parts. Part one outlines the transnational space created when American translators transformed German fiction into new products for American readers. Here Tatlock frames these books as a consumer good "altered by a process of Americanization" and situates her extensive analysis of seventeen female German authors firmly within the world of nineteenth-century American publishing using clear bar graphs (15). In part two, Tatlock extends this analysis, providing a close reading of German author E. Marlitt's popular novels, including an examination of marriage as a lens into German gender relationships. A strength of Tatlock's methodology is her ability to situate each German novel in the transnational context of current literature. For example, she compares Marlitt's character Bertha in Gold Elsie to Bertha Mason in Charlotte Brontë's Jane Eyre (56). Such subtle moments of contextualization mark the intersection of Tatlock's effort to present translated novels "both as commoditized books and as texts requiring interpretation" (24).

Part three brings Tatlock's analysis into alignment with Women of Two Countries and Gender and the Long Postwar by focusing on American translators as agents of cultural transfer and Americanization. Tatlock specifically characterizes translators Ann Mary Coleman, Annis Lee Wister, and Mary Stuart Smith as "Three Americanizers" (195). Defining Americanization as "processes by which Americans took up, responded to, and adapted German cultural material for their own purposes," Tatlock argues that Coleman, Wister, and Smith "shaped the consumption of Germany by American readers" $(12,196)$. Drawing on each translator's correspondence, Tatlock illustrates how the three women created the "hybrid" product of translated German fiction and the ways in which their publishers increasingly marketed these books as American products. Over time, Tatlock concludes, US publishers increasingly branded novels that began in the category of "family fiction" in Germany as novels specifically for women (265).

Indeed, the Germany portrayed in German Writing, American Reading, reflected family-centered themes of love, marriage, and happy endings that, as Tatlock establishes through library borrowing records, appealed to a broad spectrum of American women. The three American translators demonstrated a significant amount of individual agency, facilitating trans- 
national encounters between German and American women. In Women of Two Countries, the American studies scholar Michaela Bank similarly explores the agency of three German women in the United States who mediated between the American women's rights movement and the German American community.

Bank sees nativism as a key challenge to the idea of universal female experiences in the United States and Germany during the early American women's rights movement (1848-1890). Like Tatlock, Bank describes German and American encounters in a transatlantic space located almost exclusively within the physical boundaries of the United States. Geographic proximity, however, did not prevent conflicts between German and American women's rights activists. Building on historical critiques of universal sisterhood in the post-1890 movement (by such scholars as Aileen Kraditor and Suzanne Marilley), Bank notes a general absence of similar scholarly scrutiny for the mid-nineteenth century. ${ }^{1}$ Furthermore, she challenges existing historiography for implying that "nativism, racism, and other forms of social hierarchization were merely political tactics of an otherwise good and liberal emancipation movement" (13). Bank defends this assertion by demonstrating the effect of nativism on the German Americans who occupied the transatlantic political space of the American women's movement $(13,166)$. According to Bank, the biographies of three German American women-Mathilde Wendt, Mathilde Franziska Anneke, and Clara Neymann-reveal a range of tactics these women employed against nativist arguments in the women's rights movement.

In Women of Two Countries Bank emphasizes the importance of German American women's lived experiences of nativism in the women's rights movement. These women found themselves in the role of mediators or, in a similar fashion to Tatlock's agents of cultural transfer, "translators" between the women's movement and the German American community. Bank portrays her first case, Wendt, as an early mediator between the two groups, yet she is the only woman who does not receive her own chapter, structurally reflecting Bank's assertion that she was not as prominent in the mainstream American women's movement as Anneke and Neymann $(44-45,168)$.

Bank, importantly, uses Wendt and Anneke as case studies to effectively illustrate the divisions within the German American community. When the women's movement split between the National Woman Suffrage Association (NWSA) and the American Woman Suffrage Association (AWSA) in 1868, Wendt supported the AWSA, and Anneke remained loyal to Susan B. Anthony and Elizabeth Cady Stanton in the NWSA $(3,52)$. This split reveals a heterogeneous transatlantic space for German American activism that scholars have overlooked as simply a homogenous foil to American nativist arguments. 
Transnational encounters between German women and the American women's rights movement feature prominently in Bank's examples of Anneke as a "powerful translator" and Neymann as a mediator in both the literal and figurative sense, providing a clear lens into nativist tension in the movement $(68,120)$. Anneke occupied liminal space between the women's rights movement and the German American community, serving as liaison and interpreter for both. Anneke attracted attention from mainstream women's rights activists by virtue of her experience as a German American woman, yet her inability to articulate her arguments-though conspicuously non-nativist arguments-in English limited her personal impact in the movement (105).

As Bank demonstrates, Neymann was also marked by her ethnicity. Although Neymann negotiated transatlantic spaces more freely, partly based on her own personal mobility and multilingualism, Bank argues that ethnicity was "inscribed on Neymann's body" after a failed 1882 suffrage campaign in Nebraska "and seemed to be inescapably present" in media descriptions $(133,147)$. Through these three German American biographies, Bank reveals the women's potential as cultural mediators and the limits of their acceptance in the American women's rights movement due to nativist preferences. This tension between national contexts and transatlantic agents is a central theme in Hagemann and Michel's edited volume, Gender and the Long Postwar.

Hagemann and Michel address the issue of positionality in Gender and the Long Postwar. The editors open with Tony Judt's argument that "World War II created the conditions for a new Europe" and question if this statement applies to the postwar United States as well as to East and West Germany (1). Here, a subject's position within this broader Cold War framework mattered since images of the ideal woman and motherhood, as well as (re)constructions of masculinity, were often used as foils against one another (3). By juxtaposing postwar developments in the United States, Soviet Union, Federal Republic of Germany (FRG), and German Democratic Republic (GDR), Hagemann and Michel have produced an excellent platform for continued research on entangled history through gender analysis. Each essay focuses on lived gendered experiences in World War II and the Cold War, reinforcing the editors' bold claim that a "primary focus on gender allows us to undertake a comprehensive interrogation and revision of much of the social, economic, and political historiography of the period from a fresh perspective" (4).

Fluid connections between essays in this diverse volume attest to Hagemann and Michel's experience as editors. The fifteen contributors range in rank, discipline, and geographic focus. The volume is divided into four parts focusing on the aftermath of World War II; militarism, politics, 
and masculinity; family and the welfare state; and constructions of sexuality and gender identity. As expected of an edited volume, conceptions of transatlantic and transnational space vary in each contribution. While Ulrike Weckel, Rebecca Boehling, Alice Weinreb, and Kathleen Nawyn explicitly link German and American contexts in their chapters, Robert Moeller and Jennifer Evans focus primarily on West and East German efforts, respectively, to decriminalize homosexuality after World War II. The transnational space between the two Germanys, therefore, also provides context for entangled history.

The editors' focus on the United States and the two Germanys reveals inequalities in both scholarship and historical case studies. Extending gender analysis of World War II and Cold War history beyond single national historiographies, Hagemann and Michel's volume reveals key paradoxes in gender history. For example, American occupiers in Germany promoted gender equality although gender inequality characterized postwar American society through programs like the GI Bill (8). In terms of scholarship, contributions by such scholars as Laura McEnaney, Amy Rutenberg, Steve Estes, and Jennifer Mittelstadt focus primarily on events in the United States. In contrast, most essays set in Germany prove fertile ground for transatlantic and transnational analysis and suggest the absence of a similarly dynamic postwar dialogue between Germans and Americans in the United States.

Read in tandem with Tatlock and Bank, this absence of explicit German influences in the United States after 1945 is all the more striking. Perhaps this disconnect can be explained by the frequent and direct postwar contacts between Americans and Germans within German borders due to occupation and relief efforts, which contrasts to the relative absence of similar conditions in the United States. The US-focused essays, Donna Harsch's examination of the East German welfare state, and Atina Grossman's study of German memory of sexual violence nonetheless reference broader themes: Cold War context and the aftermath of World War II, addressing each nation's relationship to the wider world. Like Tatlock and Bank, Grossmann and Boehling emphasize female agency in their contributions to Gender and the Long Postwar. Grossmann challenges prevailing narratives of German women as victims of rape, urging scholars "to take seriously women's own portrayals of themselves as resourceful agents" (33). In addition, Boehling highlights the agency of local female politicians in 1940s and 1950s Munich who drew on their experiences from the Weimar Republic and World War II to demand equal pay for equal work. This political agency was limited, as Boehling's research reveals, by the intervention of American occupation authorities and the projection of American gender assumptions on German women (62). Women are not the only understudied cultural agents that contributing scholars emphasize in Gender and the Long Postwar. Steven Es- 
tes complicates the homogeneity of the "greatest generation" in the United States by recognizing World War II as a formative experience for both African American soldiers (who later took part in the civil rights movement) and southern, white World War II veterans. Both groups leveraged their individual war narratives and agency as soldiers and citizens to reposition themselves in postwar society (200).

All three studies consider the family as a site of gender analysis and, by extension, the portrayal of "normal" gender roles and tensions between public and private. Tatlock devotes a considerable part of her analysis to gender roles portrayed in German novels. In particular, Tatlock reads in the Schillingscourt as a narrative of an American woman remaking a German man, linking both American and German subjects with the reconstruction of universal masculine gender roles within the family unit while "foregrounding" the female protagonist (77).

In Women of Two Countries, Bank examines German traditionalist gender relations employed by the suffragist Elizabeth Cady Stanton in an 1869 speech. Stanton "prominently repeated the image of the German woman, who was yoked side by side with an ox to a plow and driven by a German man" (80). Her statement, unsurprisingly, offended German Americans in the audience; and Stanton cited Anneke as her source for the image. Here Anneke's tenuous position as mediator between the women's rights movement and German American community becomes apparent. To downplay Stanton's blatantly nativist use of this image, Anneke later emphasized its role as a "rhetorical metaphor" and extrapolated the image's meaning as a comment on all women who suffered from "patriarchal legal and social conditions" (84). In other words, Anneke transferred a culturally specific German image to transatlantic space that stressed the universal experience of discrimination against women.

Rebecca Boehling and Jennifer Mittelstadt take the analysis of stereotypical gender roles within the family further in Gender and the Long Postwar, critiquing assumptions about the role of the male breadwinner in postwar German and American society and demonstrating its long-term effects. Boehling claims American military authorities in Munich applied their own bias against female employment, believing that a postwar gender order featuring male bread winner families would expedite demobilization (52). In addition, West German women who advocated for women's rights issues, like equal pay, were often labeled as communist and presented a challenge to American perceptions of the traditional gender order during the Cold War $(62,64)$. In the American context, Mittelstadt reveals a similar bias in American government policies. She interrogates the male breadwinner family model, arguing that the American postwar military welfare system, galvanized by images of uniformed soldiers in poverty, assumed 
that soldiers' wives would stay home (281). In both cases, American officials' assumptions about the ideal of a male breadwinner family shaped long-term gender relations in both the United States and West Germany after World War II.

German Writing, American Reading, Women of Two Countries, and Gender and the Long Postwar are critical interventions by women's historians and gender scholars in the growing field of transnational studies in a transatlantic setting. The authors represent a range of interrelated disciplines-from German and American studies to history-yet their application of gender analysis reveals common themes on both sides of the Atlantic surrounding individual agency, traditional gender roles, transnational encounters, and the family. Taken together, they provide a solid foundation for future scholarship on gender and German-American encounters.

\section{Notes}

${ }^{1}$ Aileen S. Kraditor, The Ideas of the Woman Suffrage Mozement, 1890-1920 (New York: Columbia University Press, 1965); and Suzanne M. Marilley, Woman Suffrage and the Origins of Liberal Feminism in the United States, 1820-1920 (Cambridge: Harvard University Press, 1996). 